\title{
Reflections on Thyroid Autoimmunity: A Personal Overview from the Past into the Future
}

Authors

Basil Rapoport, Sandra M. McLachlan

Affiliation
Thyroid Autoimmune Disease Unit, Cedars-Sinai Medical
Center and UCLA School of Medicine, Los Angeles, CA, USA

Key words

Graves' disease, TSH receptor, autoantibodies,

thyroid peroxidase, thyroglobulin

received 21.06 .2018

accepted 23.08.2018

Bibliography

DOI https://doi.org/10.1055/a-0725-9297

Published online: 24.10 .2018

Horm Metab Res 2018; 50: 840-852

(c) Georg Thieme Verlag KG Stuttgart · New York

ISSN 0018-5043

\section{Correspondence}

Basil Rapoport, MB, ChB, Sandra M. McLachlan, PhD

Cedars-Sinai Medical Center

8700 Beverly Blvd, Suite B-131

90048 Los Angeles

USA

Tel.: + 1/310/423 7680, Fax: +1/310/4230440

Basil.Rapoport@ucla.edu;

Sandra.Mclachlan@ucla.edu

\section{ABSTRACT}

After investigating thyroid autoimmunity for more than 40 years, we present a personal perspective on the field. Despite effective therapies for Graves' hyperthyroidism and Hashimoto's thyroiditis, cures are elusive. Novel forms of therapy are being developed, such as small molecule inhibitors of the TSH receptor (TSHR), but cure will require immunotherapy. This goal requires advances in understanding the pathogenesis of thyroid autoimmunity, the 'keys' for which are the thyroid antigens themselves. Presently, however, greater investigative focus is on non-thyroid specific immune cell types and molecules. Thyroid autoantigens are the drivers of the autoimmune response, a prime example being the TSHR. In our view, the TSHR is the culprit as well as the victim in Graves' disease because of its unique structure. Unlike the closely related gonadotropin receptors, the TSHR cleaves into subunits and there is strong evidence that its shed extracellular A-subunit, not the holoreceptor, is the major antigen driving pathogenic thyroid stimulating autoantibodies (TSAb) development. There is no Graves' disease of the gonads. Studies of potential antigen-specific immunotherapies require an animal model. Such models have been developed in which TSAb can be induced or, more importantly, arise spontaneously. Not appreciated until recently by thyroid investigators is that B cell surface autoantibodies are highly efficient 'antigen receptors' and the epitope to which an autoantibody binds influences antigen processing and which peptide is presented to T cells. These animal models and recombinant human autoantibodies cloned from Graves' and Hashimoto's B cells (plasma cells) are available for study by future generations.

\section{Introduction}

After studying thyroid autoimmunity for more than 40 years, we wish to present a personal perspective of how this field has evolved, some selected aspects of our contribution thereto, and where it is headed. At the outset we emphasize that this perspective is focused, not comprehensive, and that we present points of view with which some may disagree. Contributions by investigators too numerous to mention have resulted in advances in our knowledge comparable to the Wright brothers viewing a modern aircraft. Autoimmune thyroid diseases can be readily treated, yet cures remain elusive. Before forming a team, not knowing each other despite being close neighbors in South Africa where we grew up, we coincidentally began studying thyroid autoimmunity on different continents after failing to find positions in our initial fields of choice. Like other aspects in life, initial disappointments proved highly positive.

The great advantage to studying the pathogenesis and potential treatment of thyroid autoimmunity is the unequivocal identification and availability of a limited number of disease-associated, thyroid specific antigens. In the early 1970's, the clinical aspects of Grave's disease and Hashimoto's thyroiditis were well known and therapies (apart from ophthalmopathy) essentially unchanged. The major research advances had occurred two decades earlier, in 1956, with the seminal discoveries of autoantibodies to thyroglobulin (Tg) [1,2] and the microsomal antigen [3] in Hashimoto's thyroiditis, and a long acting thyroid stimulator (LATS) in Graves' disease [4], later found to 
be an $\lg G[5,6]$. These findings were fundamental in introducing the concept of autoimmune diseases in general, with the importance of autoantibodies followed later by the role of T cells. For thyroid-specific autoimmunity, the discovery of autoantibodies and the development of clinical assays for their detection introduced a new dimension in studying the pathogenesis of these diseases, with subsequent advances reviewed in the following sections.

Immunological journals are replete with studies on other autoimmune diseases (both organ-specific and systemic) describing associations with varying permutations of the ever-expanding compendium of cytokines, chemokines and different immune cell types, including $T$ and $B$ cell variants and their panoply of receptors and cell surface proteins ("CD-x"). Only rarely do such studies involve an autoantigen unequivocally involved in disease pathogenesis, such as in myasthenia gravis. Even in type I diabetes mellitus, there is debate as to which of a variety of antigens is the initial target in disease pathogenesis as opposed to being secondary markers of organ damage.

Rather than delving into the immunological molecule or cell type "du jour"-, our approach has primarily been to take advantage of the 'gift' provided by disease associated thyroid antigens. To paraphrase the campaign statement by President Bill Clinton on the economy: "It's the autoantigen, stupid". Thyroid autoantigens are crucial keys for studying thyroid autoimmunity. Autoimmune responses require the appropriate interactions between T cells, B cells and antigen presenting cells and the location of these cells in lymphoid organs including lymph nodes and (for thyroid autoimmunity) the thyroid itself [7]. However, the drivers of thyroid autoimmunity are the autoantigens. The availability of recombinant (TPO) and the TSH receptor (TSHR) for the past 20 years, made possible by the molecular cloning of their genes (reviewed in $[8,9]$ ), has been critical for studies on the pathogenesis of thyroid autoimmunity, including the loss of immunological tolerance to these autoantigens (reviewed in [10]), as well as the development of improved diagnostic assays and the search for potential immune-therapeutic approaches.

\section{The TSH Receptor in Graves' Disease}

It may not be appreciated by new generations of investigators that the concept of hormone action being mediated by binding to a cognate receptor was introduced with the TSH receptor (TSHR) [11]. This fundamental discovery led to the development of progressively more convenient, sensitive and specific assays for TSHR autoantibodies in Graves' disease. Besides their clinical value, these assays are essential for studies on the pathogenesis of thyroid autoimmunity.

\section{a) TSHR autoantibody assays}

Detection of thyroid stimulators (TSH, LATS, TSAb) by laborious assays involving release of radioiodine from prelabeled rodent thyroids was supplanted by two types of new assays, developed in the 1970s: (i) a bioassay using cultured thyroid cell monolayers for measuring TSHR activation [12] and, (ii) a TSH binding inhibition (TBI) assay involving competition by Graves' IgG for radiolabeled TSH binding to thyroid membranes [13]. The past 45 years have seen numerous modifications of these assays and investigation into the value of their clinical use, with a vast literature beyond the scope of this article. However, we can comment on the present state of these assays.

Competing assay manufacturers target clinicians and laboratories with advertisements claiming superiority, often with misleading or erroneous assertions regarding their ability to measure functional TSAb and the potential influence of TSH blocking antibodies (TBAb; sometimes incorrectly termed 'thyroid' blocking antibodies). In particular TBI assays, including the substitution for TSH of a monoclonal human TSAb [14], are criticized by manufacturers of bio- [15] and bridge assays [16] for using the wild-type TSHR, not a modified, chimeric TSHR, which supposedly avoids the confounding influence of TBAb in detecting TSAb in a patient's serum. Following a report 20 years ago [17], the generally accepted mantra has arisen that "TSAb bind to the N-terminus and TBAb bind to the C-terminus" of the TSHR extracellular domain (ECD). Based on this concept, replacing the TSHR C-terminal TBAb epitope with the equivalent region of the related, luteinizing hormone receptor would generate a chimeric receptor recognized only by TSAb and not by TBAb. Unfortunately, this concept is only partially correct. Unlike TSAb, which universally recognize the TSHR N-terminus (for example [18-20], TBAb epitopes are not localized, but are widely distributed with many occurring at the TSHR N-terminus besides the C-terminus [19, 21, 22]. Indeed, the atomic structure of a monoclonal human TBAb (K1-70) in complex with the TSHR reveals binding entirely to the receptor N-terminus [23] and very similar to that of a monoclonal human TSAb (M22) [20]. Finally, the chimeric TSHR used in the commercial bioassay and bridge assay are 'seen' by some TBAb [16, 24]. TBAb can reduce the stimulatory effect of TSAb in vitro [21,25] as well as in vivo [26]. Therefore, even a bioassay (whether using a chimeric or wild-type TSHR) whose 'readout' is a signal for TSHR activation rather than ligand binding is not immune from interference by TBAb, if present in the same serum.

The question also arises as to how important (as urged by advertisers) is the possible presence of TBAb together with TSAb in the serum of a hyperthyroid patient? TBAb activity sufficient to cause hypothyroidism and thyroid atrophy are extremely rare relative to hyperthyroid patients with a diffuse goiter. Therefore, in the latter situation, it is irrelevant whether TBAb, if present concurrently with TSAb, contribute to a positive TBI or bridge assay. The net effect is thyroid stimulation. Determining both TBAb and TSAb is theoretically of potential value in some Graves' patients in whom hyperthyroidism can rarely swing spontaneously to hypothyroidism and vice versa [27]. However, detecting TBAb activity in a serum with TSAb is not straightforward. TBAb are measured indirectly in a bioassay by their ability to reduce TSHR activation by a potent added ligand, TSH. A basic pharmacological principle is that a weak agonist is also an antagonist. It has been known for decades that TSAb binding overlaps with that of TSH [13], a finding confirmed at the atomic structural level [28]. Therefore, if TSAb potency in a Graves' serum is less than that of the added TSH, the former will reduce TSH stimulation and can be interpreted as having TBAb activity. Many reports describing the current presence of TSAb and TBAb activities in the same serum are, therefore, open to question. The most definitive way to determine the presence of both TSAb and TBAb in an individual serum is to isolate them independently and demonstrate their specific, non-overlapping stimulatory or in- 
hibitory activities. To our knowledge there has been only one such demonstration [29].

In summary, in Graves' disease the TBI and bridge assays, though not bioassays, do measure TSAb. In the vast majority of cases, the influence of TBAb in serum (if actually present) is not relevant in the presence of hyperthyroidism. TSAb bioassays (regardless of whether utilizing a chimeric or wild-type TSHR) provide similarly useful information, but are influenced in the opposite direction to TBI and bridge assays; TBAb, if present, will reduce the reported TSAb activity. Favoring TBI and bridge assays is that they are less complex, amenable to automation with a more rapid turn-around time, and cheaper than bioassays. Finally, the term TRAb (TSHR antibody) commonly used for TBI assays does, in fact, refer to all TSHR autoantibody assays.

\section{b) Role of the TSHR structure in Graves' disease; the culprit as well as the victim}

The TSHR undergoes intramolecular cleavage into an A-subunit comprising the $\mathrm{N}$-terminal portion of the extracellular domain (ECD) linked by disulfide bonds to a largely transmembrane B-subunit [30] ( $>$ Fig. 1). It has long been known that the ECD is labile and shedding of a component, the A subunit or a fragment thereof, is enhanced under non-physiological conditions such as freeze-thawing membranes [31] or enhanced by cells made 'sick' by prolonged culture in medium with a greatly reduced fetal calf serum concentration [32,33]. Studies under the latter artificial conditions led to speculation that pathophysiological shedding of an ECD component could play a role in thyroid autoimmune diseases or cancer.

Generation of mouse monoclonal antibody (mAb) 3BD10 [34], to the isolated TSHR A-subunit ('TSHR-289') secreted by transfect- ed CHO cells [18] has led to a cascading series of observations with a major impact on our understanding of the pathogenesis of Graves' disease. To our initial disappointment, despite strong recognition by ELISA of the recombinant TSHR A-subunit (the immunogen), 3BD10 failed on flow cytometry to recognize the TSHR holoreceptor on the cell surface. In a serendipitous event that occurs only occasionally in a lifetime, a week after the 9/11 disaster Dr. Alan Johnstone in London e-mailed us to offer a mAb that, unlike our 3BD10, did recognize the TSH holoreceptor [35]. Coincidentally at the time we were traveling from Los Angeles to South Africa via London. In an unparalleled example of scientific generosity, Dr. Johnstone came to meet us in transit at Heathrow and gave us an aliquot of his $\mathrm{mAb}$ $3 \mathrm{E} 5$. Returning to our laboratory 2 weeks later we tested $3 \mathrm{E} 5$ which, like our 3BD10, was negative on flow cytometry with the holoreceptor. Our initial thought that the mAb had 'died' was ruled out when 3E5, again like 3BD10, was strongly positive with the A subunit on ELISA. To understand the discrepancy between our labs as to $\mathrm{mAb}$ recognition of the TSH holoreceptor, we asked Dr. Johnstone what TSHR expressing cell line he used. It was a cell line expressing the identical TSHR ECD anchored to the cell membrane by a small, flexible lipid molecule [glycosyl phosphatidylinositol (GPI)] rather than the hepta-helical transmembrane domain [36]. Confirmation in our lab of this differential recognition (TSH holoreceptor vs. TSHR-ECD-GPI) led us to hypothesize and, indeed, establish that TSAb in Graves' sera similarly recognize the flexible ECD to a far greater extent [37] and with higher affinity [38] than the TSH holoreceptor. These data indicated partial steric hindrance for TSAb binding to the TSH holoreceptor, suggesting a mechanism by which these autoantibodies activate the receptor $[37,39]$. Further, the data suggested that affinity maturation of high affinity TSAb did

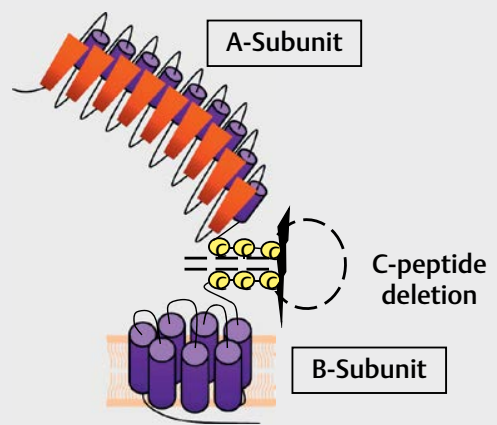

TSH Holoreceptor

- Activated by TSAb in thyroid and extra-thyroidal tissues

- TSAb and TBAb bioassays use TSHR expressing CHO cells

- TSHR + MHC class II expressing fibroblasts induce TSAb and hyperthyroidism in autologous (AKR/N) mice

- Plasmid TSHR-DNA injected into mice induces TSAb in (BALB/C), as well as hyperthyroidism in outbred mice

- "Neutral/cleavage region" antibodies can only bind to the uncleaved TSHR with C-peptide intact

\section{TSHR A-subunit}

- Recombinant A-subunit secreted by CHO cells purified in 'active' and 'inactive' forms Only 'active' A-subunits neutralize TSAb in Graves' sera

Evidence that 'active' TSHR A-subunit is a trimer and 'inactive' is a dimer

- TSHR A-subunit, not the uncleaved holoreceptor, preferentially induces TSAb in mice

- Monoclonal human TSAb (M22) and TBAb (K1-70) both bind to the A-subunit

- Graves' ophthalmopathy model induced by A-subunit cDNA + electroporation

- A-subunit pre-treatment before A-subunit-adenovirus immunization attenuates hyperthyroidism

- Human A-subunit transgene targeted to thyroid, expressed in thyroid and thymus, induces central tolerance

- Regulatory T cell depletion switches response to A-subunit adenovirus immunization from Graves' to Hashimoto's disease (hypothyroidism, Tg and TPO antibodies)

- NOD. $\mathrm{H} 2^{\mathrm{h} 4}$ mice with A-subunit transgene in thyroid spontaneously develop TSAb

- A-subunit protein injected into TSHR/NOD.H2 ${ }^{\mathrm{h} 4}$ mice enhances TSAb development:crucial difference between induced vs spontaneous model

- Fig. 1 Developments consequent to the molecular cloning of the TSHR. Schematic illustration of TSHR structure, cleavage and A-subunit shedding (reproduced with permission from the Endocrine Society from: Rapoport B, McLachlan SM. TSH receptor cleavage into subunits and shedding of the A-subunit; a molecular and clinical perspective. Endocr Rev 2016; 37: 114-34). Other references in the text. 
not involve exposure of B cells to the TSH holoreceptor, but to a 'liberated' extracellular component, the shed A-subunit.

Support for this hypothesis was made possible by the development of induced models of Graves' disease. For decades, thyroiditis could be induced by immunizing animals with thyroid antigen (thyroglobulin) in adjuvant. However, such an approach with thyroid extracts or recombinant TSHR protein did not generate TSAb able to activate the endogenous TSHR in vivo and cause hyperthyroidism. The breakthrough occurred with the demonstration in 1996 by Shimojo et al. that in vivo expression of the native TSHR was necessary for TSAb induction, attained by injecting mice with intact fibroblasts expressing the recombinant TSHR together with the autologous MHC class II molecule [40]. This in vivo expression approach was then extended to inducing hyperthyroidism in other mouse strains independent of MHC by DNA vaccination with a plasmid [41] or adenovirus vector [42] encoding the TSH holoreceptor. The latter model was used to test the shed A-subunit hypothesis mentioned above. Injecting an adenovirus expressing only the TSHR A-subunit induced TSAb and hyperthyroidism in a high proportion of BALB/C mice. In contrast, injecting an adenovirus encoding a TSH holoreceptor modified in its cleavage site to prevent cleavage and subsequent A-subunit shedding induced TSHR antibodies without TSAb activity and no hyperthyroidism [43].

It is noteworthy that the closely related $\mathrm{FSH}$ and $\mathrm{LH}$ receptors do not cleave into subunits and there is no Graves' disease of the gonads. In this respect, we described the TSHR as the culprit as well as the victim. Expression of the wild-type TSH holoreceptor does induce TSAb and hyperthyroidism, presumably by shedding of some of its cell surface A-subunits, but less effectively than in vivo expression of the free A-subunit. Consequent to this observation, it has become the general practice in different laboratories to study animal models of Graves' disease induced by free A-subunit expression in vivo, using either an adenovirus vector or plasmid vaccination made more effective by electroporation [44]. The first mouse model of Graves' ophthalmopathy was recently reported using the latter method [45].

Another finding of pathogenetic significance that would not have been made without TSHR mAb 3BD10 was that affinity purified recombinant TSHR A-subunits secreted by $\mathrm{CHO}$ cells [18] existed in two conformational forms, which we termed 'active' and 'inactive' [46]. Active A-subunits in solution neutralized TSAb but were not recognized by 3BD10. Conversely, on ELISA inactive A-subunits were recognized by 3BD10 but not by TSAb. This differential recognition by $3 \mathrm{BD} 10$ enabled the separate purification of active and inactive TSHR A-subunits, both heavily glycosylated and with identical primary amino acid sequences [46]. Moreover, both A-subunit forms were conformationally 'native', with TSAb and 3BD10 recognition eliminated upon denaturation. Purified active A-subunits spontaneously converted to the inactive form in a time and temperature dependent manner, a process stopped by the addition of chemical chaperones [46]. Only 15 years later, after crystallization of the 3BD10 Fab and solving of its atomic structure by $x$-ray diffraction did a feasible explanation for the structural and behavioral differences between 'active' and 'inactive' TSHR A-subunits become apparent. In silico docking of the 3BD10 structure with the TSHR A-subunit structure [20] revealed that both 3BD10 and TSAb could bind to an A-subunit monomer but, instead, pro- vided evidence that active and inactive A-subunits were multimeric, being trimers and dimers, respectively [47].

The foregoing findings permitted addressing the question of whether the TSHR immunogen in Graves' disease is a monomer or multimeric. If a monomer, then autoantibodies in Graves' patients' sera should recognize both active and inactive A-subunits, as occurs in mice immunized with vectors coding for the isolated A-subunit [10]. However, testing of a large panel of Graves' sera revealed recognition of only active $A$-subunit forms, providing evidence that multimeric, not monomeric, A-subunits initiated and/or amplified affinity maturation of pathogenic TSAb in the pathogenesis of Graves' disease [48]. The TSH holoreceptor on the cell surface exists as a multimer $[49,50]$ and A-subunits could be shed either as multimers or form multimers after drainage to regional lymph nodes. Unlike A-subunits shed from the holoreceptor, DNA vectors and thyroid-targeted transgenic mice express the free A-subunit some of which is more likely to persist as a monomer, thereby inducing antibodies to both active and inactive A-subunit forms.

\section{c) TSHR A-subunit transgenic mice; regulatory T cell-mediated balance between Graves' disease and Hashimoto's thyroiditis}

Insight into the importance of the shed TSHR A-subunit in the pathogenesis of Graves' disease, together with prior knowledge that A-subunits stably expressed in mammalian cells were largely secreted [18] led to the generation of transgenic mice (BALB/C background) expressing the human TSHR A-subunit targeted to the thyroid gland [51]. One line of mice expressed high levels (Hi-expressor) and the other low levels (Lo-expressor) of the A-subunit in the thyroid gland. Lo- but not Hi-expressors developed pathogenic TSHR antibodies when immunized with high doses of adenovirus encoding the human TSHR A-subunit [52]. Unlike, non-transgenic littermates, neither responded to low immunization doses. These findings indicated different levels of self- tolerance to the transgenically expressed A-subunit, which correlated with the amount of human TSHR A-subunit expressed in the mouse thymus [51, 52]. Indeed, later studies in humans demonstrated that TSHR mRNA transcripts expressed at low levels in the thymus are associated with susceptibility to Graves' disease while high intra-thymic TSHR mRNA levels are protective [53, 54].

An attempt to overcome self-tolerance and boost the response to A-subunit immunization in Lo-expressor transgenic BALB/c mice by depleting regulatory T cells (Treg) using antibody to CD25 failed to enhance TSHR antibody levels but led to a result diametrically opposite to the hypothesis. Remarkably, the mice developed hypothyroidism in association with massive lymphocytic infiltration, elevated serum TSH levels and with antibody spreading to mouse $\mathrm{Tg}$ and mouse TPO, in other words Hashimoto's disease [55]. It is well known that Graves' disease and Hashimoto's thyroiditis can co-exist or evolve from one to the other. The foregoing observations suggest an important role for Treg in this balance.

\section{d) A mouse strain that spontaneously produces TSAb; hope for future immunotherapy for Graves' disease}

For approaching a century there has been no change in therapeutic approaches for Graves' disease. Thionamide drugs, radio-iodine and surgery are all effective in treating hyperthyroidism, but none 
can cure the disease. The goal of an immunotherapeutic cure is to blunt or reverse the spontaneous generation of TSAb by the immune system. Studies to attain this goal have been handicapped by the prior unavailability of an animal that spontaneously develops TSAb. Indeed, it is remarkable that only humans, not even great apes [56], develop TSAb with consequent Graves' disease. In contrast to TSAb, several animals spontaneously develop thyroiditis associated with autoantibodies to Tg, typically accelerated by ingestion of excess iodide. Best studied are NOD. $2_{2}{ }^{\mathrm{h} 4}$ mice [57] in which antibodies to TPO also arise a few months later than those to $\mathrm{Tg}$ [58]. However, NOD. $2^{\mathrm{h} 4}$ mice do not develop antibodies to the TSHR.

The hypothesis that introducing the human TSHR A-subunit into the thyroid of autoimmune-prone NOD. H2 ${ }^{\mathrm{h} 4}$ mice would lead to the spontaneous generation of antibodies to the TSHR proved to be correct. TSHR/NOD. $2_{2}{ }^{\text {h4 }}$ mice were obtained by back-crossing Lo-expressor human TSHR A-subunit BALB/c transgenics to NOD. $\mathrm{H} 2{ }^{\mathrm{h} 4}$ mice. Pathogenic TSHR antibodies (detected in TBI and TSAb assays) as well as non-pathogenic TSHR antibodies (ELISA) are present at 6 months of age, about 2 months later than $\mathrm{Tg}$ antibodies [59], and persist up to 10 months, the latest point studied [60]. The TSHR/NOD.H2 $2^{\text {h4 }}$ mice do not become hyperthyroid because the TSAb arise to the human TSHR A-subunit expressed by the transgene and do not cross react with the TSH holoreceptor on the thyroid of this mouse strain (like C57BI/6 and unlike BALB/c mice) [61]. Remaining euthyroid, the TSHR/NOD.H2 ${ }^{\mathrm{h} 4}$ mice have been criticized as a model for Graves' disease. However, the goal of immunotherapy for Graves' disease will be to prevent or reverse the development of TSAb, and remaining euthyroid is an advantage because of the diverse confounding effects of thyrotoxicosis on the immune system.

Numerous approaches to immunotherapy in induced animal models of Graves' disease have targeted various cell types or molecules in the immune system (reviewed in [60]). However, effective TSHR antigen-specific therapy without affecting other aspects of the immune system is the ideal goal. Such studies, requiring substantial quantities of recombinant TSHR protein are in their early phase with limited information presently available. In an induced model (BALB/C mice immunized with hTSHR A-subunit adenovirus), injecting A-subunit protein ameliorated the development of hyperthyroidism by diverting pathogenic TSHR antibodies to non-functional TSHR antibodies detected by ELISA [62]. This effect was specific for glycosylated, eukaryotic (not prokaryotic) TSHR protein and was not observed using mouse Tg as a control. Moreover, the diversion was only effective if TSHR A-subunit protein was injected before A-subunit adenovirus immunization, not after hyperthyroidism was established.

In contrast to these findings for induced Graves' disease, injecting A-subunit protein into hTSHR/NOD. $2_{2}{ }^{\mathrm{h} 4}$ mice did not blunt the spontaneous development of pathogenic and non-pathogenic TSHR antibodies [60]. Indeed, levels of these antibodies were enhanced, presumably because the immune response to the TSHR autoantigen was already ongoing. Clearly, novel, antigen-specific immunotherapeutic approaches involving different modes of TSHR antigen presentation will be necessary to treat an established immune response, with the $\mathrm{hTSHR} / \mathrm{NOD} . \mathrm{H} 2^{\mathrm{h} 4}$ mice being an ideal vehicle for this endeavor (discussed further below).

\section{e) 'Neutral' TSHR autoantibodies}

Recent reports that 'neutral' TSHR autoantibodies play an important role in Graves' disease $[63,64]$ are generating interest and increasing recognition. The term 'neutral' is now considered to be a misnomer in that these antibodies signal via multiple non- $G$ protein pathways that increase generation of reactive oxygen species and other pro-inflammatory cascades leading to thyrocyte apoptosis and thyroid inflammation in Graves' disease and autoimmune thyroiditis [63-65]. In this sense neutral antibodies are proposed to counter balance TSAb-induced thyrocyte hyperplasia in a yinyang manner.

In our opinion, however, evidence for the existence of neutral TSHR antibodies in humans remains inconclusive, for several reasons:

i) Reports of 20-30 years ago that Graves' IgG recognize synthetic, linear peptides are cited in support of the presence of neutral antibodies [63-65]. However, these observations were assumed, incorrectly, to represent binding by TSAb or TBAb to linear TSHR epitopes (reviewed in [9]). Extrapolating these findings to the current neutral autoantibody thesis may not be valid.

ii) Neutral autoantibodies have linear epitopes within TSHR amino acid residues 322-356 [63], an area within the C-peptide region that is deleted when the TSHR cleaves into disulfide linked A- and B-subunits (reviewed in [66]) (• Fig. 1). For this reason, the proponents of neutral TSHR autoantibodies have renamed them "cleavage region" TSHR antibodies (C-TSHR-Ab) [64]. A corollary for cleavage region autoantibodies is that they can only bind to single chain TSHR in which the C-peptide cleavage region is present and not to cleaved, two-subunit receptors that lack this region. However, for many years, the prevailing concept, including by the advocates of neutral TSHR autoantibodies [67], has been that all, or the majority of, mature TSHR on the surface of thyrocytes are cleaved into subunits and lack the C-peptide region, and that single chain receptors are an artifact of transfected non-thyroidal cells [68-70]. Contrary evidence that a substantial proportion of TSHR on intact thyroid cells do, indeed, exist in single chain format $[66,71,72]$ remains overlooked and awaits recognition to address this paradox.

iii) Description of the methodology used to demonstrate the presence of cleavage region TSHR autoantibodies in Graves' sera is complex and difficult to follow (for example [63]). Moreover, the functional effects of neutral antibodies have only been reported for rodent $\mathrm{mAb}$ and not for polyclonal Graves' IgG.

Therefore, conclusive proof for the existence of functional, human neutral TSHR autoantibodies will await the cloning of human mAb of this variety, as has been accomplished for human TSAb [73] and TBAb [74].

\section{f) Extrathyroidal manifestations of Graves' disease}

Therapy for these distressing conditions remain more challenging than for Graves' hyperthyroidism. Future, more effective treatment modalities depend on advances in understanding their pathogenesis. In Graves' ophthalmopathy (GO), increased hyaluronan generation and edema is caused by an immune response to the TSHR 
expressed on fibroblasts/preadipocytes. We take issue with the prevailing opinion expressed in a current major textbook that cellular immunity ( $T$ cells) is most important in initiating GO and that 'locally' produced TSAb (humoral immunity) provide 'additional' effects on orbital tissue [75]. Certainly, T cell help is necessary for B cell maturation and a variety of cytokines of T cell origin can induce hyaluronan overproduction. However, lymphocytic infiltration of orbital tissue is relatively sparse, generating a cytokine profile similar to that in normal tissue and different from that in other orbital inflammatory conditions [76]. GO and Graves' dermopathy are associated with very high levels of TSAb that markedly stimulate hyaluronan (HA) production by orbital fibroblasts, even before differentiation into adipocytes $[77,78]$. Moreover, elevation of a non-immune molecule, TSH, caused by non-compliance with thyroxine therapy, can greatly exacerbate GO to the point of requiring enucleation (personal patient). For these reasons, the humoral immunity contribution to clinical GO cannot be considered subservient to cellular immunity and may even be dominant.

A paradox needs to be addressed in understanding the pathogenesis of the extrathyroidal manifestations of Graves' disease. Why, if the TSHR is widely expressed in extrathyroidal tissues are the clinical manifestation of Graves' disease limited to the thyroid, orbital tissue and skin, the latter primarily affecting the lower extremities? There is overlooked evidence that Graves' disease is a systemic disorder with clinical localization depending on other factors. Most convincing is that urinary excretion of glycosaminoglycan (hyaluronan) is increased in GO to an extent that cannot be explained as originating from a small mass of orbital tissue $[79,80]$, as well as in Graves' disease independent of the presence of GO [81]. In the thyroid, the TSHR is linked to thyrocytes secreting thyroid hormones. So why involvement of the orbit and lower extremities? Functional TSHR protein is clearly present in fibroblasts in the upper dermis of normal tissue, such as breast [82] and other diverse locations [83] and TSAb can increase HA production by fibroblasts from individuals without Graves' disease [78]. Even though this increase is less than in Graves' orbital fibroblasts, the skin is the largest 'organ' in the body and is likely to be the major source of increased $\mathrm{HA}$ urinary excretion.

Nearly 20 years ago we put forward an hypothesis [82] that, in our opinion, remains attractive even though overlooked in the literature. We proposed an answer to the foregoing paradox in that the orbit is particularly vulnerable to clinical GO because its volume (approximately $20 \mathrm{ml}$ ) is constrained by its bony dimensions, as well as by the strength of the orbicularis retaining ligament. Even a very small increase in volume caused by HA, edema, and adipogenesis will compress low pressure venous and lymphatic vessels (similar to a 'compartment syndrome' in a limb), with reduced clearance of $\mathrm{HA}$ and cytokines thereby increasing swelling. Development of clinical GO depends on the balance between the magnitude of TSAb activity and the anatomical characteristics of the individual orbit (greater TSAb activity required in the mouse with a more open bony orbit than in humans). Orbital edema can be further increased, commonly by cigarette smoke and less frequently occurring trauma (for example botox injections and cataract surgery). In the absence of bony constraints, development of Graves' dermopathy requires more potent TSAb activity together with local factors well described in the literature such as unilateral venous insuf- ficiency or trauma [82]. An important point, contrary to descriptions in some textbooks and reviews, is that local trauma is not a significant factor in the initiation of GO and Graves' dermopathy. Most GO is not associated with trauma, but trauma may aggravate the underlying pathogenetic process analogous to the Koebner phenomenon in some cutaneous diseases [84].

It is logical that therapy of an autoimmune condition targeting a single, specific antigen such as the TSHR will be effective if this interaction is prevented. Conversely, it is self-evident that less specific targeting of molecules with functions common to orbital tissue and diverse organs or cell types, although possibly effective in treating GO, risks potentially serious side effects. For this reason, we question the present emphasis on the latter forms of therapy, the foremost example being systemic suppression of IGF-1 receptor (IGF-1R) function with Teprotumumab (monoclonal antibody to the IgF1R) [85]. It has long been known that IGF-1 acts synergistically with TSAb on thyrocytes [86] and early reports of autoantibodies in Graves' disease to the IGF-1R $[87,88]$ encouraged this therapeutic approach. It was further suggested that TSAb directly activate the IGF-1R which exists in complex with the TSHR [89]. However, recent evidence has both refuted the importance of IGF-1R autoantibodies in Graves' disease [90, 91] and has demonstrated that the TSHR and IGF-1R act independently with synergy reflecting post-receptor signaling cross-talk [91, 92]. Nevertheless, because of this synergy it is to be expected that systemic IGF-1R blockade will ameliorate GO, at least in part, but side effects with IGF-1R blockade in cancer therapy [93] raise questions whether more experience with $\mathrm{GO}$ will counter the preliminary report of its safety [85]. If activation of the TSHR in orbital tissue can be prevented, non-specific IGF-1R blockade becomes moot. Indeed, preliminary data (see below) suggest that therapy focused on the TSHR alone, independent of IGF-1R blockade, may be effective in ameliorating the signs and symptoms of $\mathrm{GO}$ [94].

Synthetic 'small molecule' TSHR antagonists have been isolated by several groups [95-97]. More antigen specific than systemic IGF-1R blockade, these molecules enter a pocket in the transmembrane domain and have relative in vitro specificity for the TSHR compared to the closely related gonadotropin hormone receptors. However, the TSHR belongs to the G-protein coupled receptor superfamily of nearly 800 members, many of which are 'orphan' with unknown function and TSHR small molecule antagonists may have unanticipated adverse actions on in vivo testing. Further molecular refinement is likely to improve specificity for the TSHR and may lead to effective treatment, but not a cure. Anti-CD20 mediated B cell depletion with Rituximab, a logical approach though not antigen specific and with potential serious side effects, has had mixed results in prospective clinical trials $[98,99]$. It should be noted that Rituximab targets pre-B cells and mature B cells not very long-lived plasma cells that are the major source of TSAb and its effect may be on antigen presentation [100] and below).

Remarkably, contrary to the need for development of antigen-specific therapy for GO, an ever-growing number of non-specific immune-related and signal transduction molecules are being proposed as potential targets for therapy in GO. Indeed, one laboratory in the past 4 years has published data on the following molecules described to be of interest in this regard; IL-1R antagonist, IL-6, IL-8, IL-12, IL-23/IL-17, TNF alpha, Slit2, CXCL-12/CXCR4, Pen- 
traxin-3, PTEN, AIRE, PCP-1, and p53 [101-108]. The modified Bill Clinton campaign slogan mentioned above deserves repeating.

\section{Recognition of Thyroid Autoantigens by $\mathrm{T}$ and B Cells}

Over the past 40 years we have witnessed great progress in understanding the role of $\mathrm{T}$ cells in the pathogenesis of autoimmune diseases, including the thyroid-related seminal discovery of cytokine-induced, 'aberrant' HLA class II expression on thyrocytes [109] that enable the former to function as antigen-presenting cells leading to T cell activation [110]. Elucidation of the atomic structures of the T cell receptor complex and MHC molecules, particularly class II, combined with information on processed antigenic peptides binding to a cleft in the former, has greatly advanced insight into autoimmune disease pathogenesis, including genetic susceptibility [111]. Advances in understanding the genetic basis for thyroid autoimmunity over these 40 years are too numerous to review here but some papers are cited in the appropriate sections. Also, we note, but do not address, the increasing interest in the role of the gut microbiome in thyroid autoimmunity (for example [112]). Finally, regarding the role of T cells in thyroid autoimmunity, in our opinion antigen specificity is the key, carrying more weight than the voluminous literature describing $T$ cell subsets such as regulatory $T$ cells in the absence of such specificity.

Reflecting on our personal contributions, a number of observations stand out. Early studies on antigen-specific lymphocytes, both T and B cells, within Graves' and Hashimoto thyroid tissue and thyroid draining lymph nodes have had a major impact on our work. In particular, cultured intrathyroidal lymphocytes, most likely plasma cells, spontaneously secreted antibodies to $\mathrm{Tg}$, the 'microsomal antigen' (TPO) and the TSHR [7, 113]. In contrast, peripheral blood lymphocytes required activation by mitogen or Epstein Barr virus. This realization opened the door to constructing human immunoglobulin heavy and light chain gene combinatorial libraries from Graves' thyroid tissue mRNA (most likely plasma cells). The availability of purified recombinant TPO [114] and Tg conventionally purified from thyroid tissue enabled screening of these libraries and the isolation of recombinant Fab specific for TPO [115-117] and $\mathrm{Tg}[118]$ ( $>$ Fig. 2). Similar studies were performed by others for recombinant human autoantibodies to TPO $[119,120]$ and $\mathrm{Tg}$ [121]. We used the same approach to isolate human autoantibodies to acetylcholine receptors from a myasthenia gravis thymus combinatorial library [122].

The molecular cloning and expression of large panels of recombinant human autoantibodies to TPO obtained from different patients' immunoglobulin gene libraries revealed that these autoantibodies essentially cover the entire repertoire of TPO epitopes in human thyroid autoimmunity, to our knowledge a unique body of information for an autoantigen [115]. Study of these TPO autoantibodies has provided much information (reviewed in [123]), including; (i) restricted heavy and light chain immunoglobulin gene usage, (ii) substantial mutation from germline sequences indicating antigen-driven, high affinity maturation, (iii) recognition of highly conformational epitopes confined to a restricted, or 'immunodominant' facet on the globular TPO molecule, unlike the recognition of diverse epitopes recognized by sera from immunized rabbits or mice (reviewed in [124]), (iv) in individual patients' sera, the spectrum of polyclonal TPO autoantibody epitopes within the immunodominant region could be 'fingerprinted', ( $v$ ) the TPO autoantibody fingerprint in an individual was not associated with the development of hypothyroidism, but, (vi) remained unchanged despite major fluctuations in antibody titer during and after pregnancy and, (vii) remained essentially unchanged over as long as 13 years, indicating a lack of epitope spreading, at least for TPO autoantibodies and, (vii) negation of the concept of bispecific human autoantibodies to both TPO and $\mathrm{Tg}$ [125]. Although progress was

\section{Tg AND TPO RECOGNITION BY T AND B CELLS}

- Thyroid infiltrating lymphocytes spontaneously secrete TgAb, TPOAb and TSHRAb, reflecting antigen-specific T and B cells (including plasma cells) Implications for constructing immunoglobulin gene combinatorial libraries Isolation of recombinant Fab specific for TPO and Tg from these libraries

- TPO-specific T cell clones isolated from thyroid infiltrating lymphocytes; expressing the TCR specific for these T cells generates a mouse strain with spontaneous hypothyroidism due to thyroiditis

- Recognition of an immunodominant region on TPO or Tg by recombinant Fab (as for serum Ab) Restricted immunoglobulin $\mathrm{VH}$ and $\mathrm{VL}$ genes Mutated from germline genes - high affinity antibodies Negation of concept of bi-specific TgPOAb

- Autoantibody epitopic fingerprints in patients' sera established using Fab specific for TPO Stable over time regardless of autoantibody fluctuations/pregnancy Not associated with hypothyroidism

- TPO Fab converted to IgE molecules permit TPO presentation to TPO-specific T cells

- Localizing amino acids in the TPO immunodominant region using TPO Fab

- Inducing TPOAb with restricted IDR recognition by injecting fibroblasts-expressing TPO and MHC class II, but not by immunization with TPO protein + Freund's adjuvant

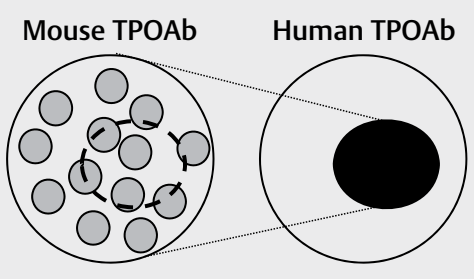

TPOAb Immunodominant Region (IDR)

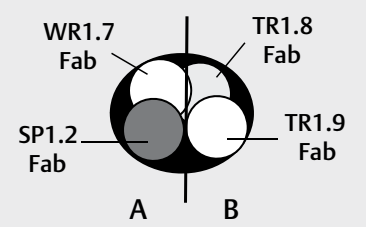

-Fig. 2 Tg and TPO recognition by T and B cells. Comparison of TPO recognition by antibodies from immunized mice versus human autoantibodies and schematic illustration of the immunodominant region (reproduced with permission from: McLachlan SM, Rapoport B. Thyroid peroxidase as an autoantigen. Thyroid 2007; 17: 939-948, 2007). 
made in identifying a number of regions and specific amino acids within the TPO immunodominant region by mutagenesis and chimeric substitutions with myeloperoxidase segments, and although the crystal structure of one human TPO Fab was solved [126], final determination of the immunodominant regions by $x$-ray crystallography remains to be accomplished.

Even though our studies focused mainly on the effector mechanisms of autoantibodies in Graves' hyperthyroidism and GO, as mentioned above, $T$ cells are obviously necessary for $B$ cell development and antibody production. Activation of thyroid antigen-specific T cells requires binding to a peptide component of this antigen inserted in the $\mathrm{MHC}$ groove (or pocket) on an antigen-presenting cell, and identifying specific peptides that contribute to disease is an important avenue of investigation with the future goal of immunotherapy. Peptide ('T cell epitope') selection in these studies on thyroid autoimmunity has been accomplished by a number of approaches:

(i) Random screening of $\mathrm{T}$ cell activation by sequential, small synthetic peptides based on the primary amino acid sequence of the antigen. Numerous early studies (including from our laboratory) produced variable findings beyond the scope of the present review.

(ii) Use of algorithms to predict the likelihood of a synthetic peptide being a T cell epitope. One TPO peptide synthesized on the basis of a T cell epitope algorithm activated a Graves' thyroid-derived T cell clone [127] and a mouse expressing the transgene of this $T$ cell receptor spontaneously developed thyroiditis [128].

(iii) Using the known atomic structure of a relevant MHC class II molecule to screen for high affinity binding of antigen synthetic peptides in silico with subsequent testing of their significance in vitro and in vivo, has identified T cell epitopes of potential importance [129] as well as evidence using tetramer technology of a combined $\mathrm{Tg}$ and TPO specific cytotoxic T cell epitope in HLA-A2 Hashimoto patients [130] .

(iv) Rather than studying synthetic antigenic peptides, approaches have been employed to identify naturally processed peptide epitopes (NPPE), the actual T cell epitopes occurring in disease. Peptides for $\mathrm{Tg}$, a protein present at extremely high concentration in the thyroid, have been extracted from HLA-DR molecules purified from Graves' thyroids [131] but no peptides from TPO and the TSHR, far less abundant proteins, were isolated.

(v) Membrane-associated immunoglobulins on B cells function as receptors for specific antigens, making these cells highly efficient in antigen presentation and NPPE generation. Unlike macrophages and dendritic cells that are non-discriminatory 'vacuum cleaners', high affinity IgG antigen receptors capture their cognate antigen even when the latter is at low concentration in a mixture of proteins, followed by internalization of the IgG-antigen complex. Importantly, antigen processing is influenced depending on the epitope to which the IgG binds, thereby determining which naturally processed peptides are presented to T cells [132].

Based on these findings, we have long considered TPO-specific, high affinity $\mathrm{lg}$ receptors on B cells to be important tools for stud- ying autoimmune thyroiditis. Cloning and expression of a repertoire of TPO human autoantibodies provided important tools for such an endeavor [133-135]. However, unable to convince NIH grant reviewers of the importance of TPO autoantibodies in antigen presentation, these studies were discontinued. We are pleased to note that more than a decade later, immunologists (as opposed to endocrinologists) are returning to the importance of B cells in the pathogenesis of thyroid autoimmunity, namely that thyroid antigen specific B cells in the circulation of recent onset patients are not anergic but express an activation marker (CD86) [136].

\section{Recent Approaches to Antigen-Specific Therapy for Thyroid Autoimmunity}

Very recently, preliminary reports on antigen-specific therapy for thyroid autoimmunity have emerged:

(i) Most dramatic is the first human study attempting immunotherapy in Graves' disease by inducing $\mathrm{T}$ cell tolerance by immunizing with TSHR peptides (ATX-GD-59)[137]. This study is based on the report that pre-treatment with these peptides blunts the humoral and cell-mediated immune responses to TSHR A-subunit adenovirus immunization of transgenic mice expressing the human HLA-DR3 molecule [138]. TSHR receptor antibodies in this mouse study were measured by ELISA, a method known to detect non-pathogenic TSHR antibodies lacking TSAb activity (for example [59,62] and data on pathogenic TSAb are not reported. Further, no information is provided on whether immunization with peptides ATX-GD-59 will have a similar effect in established disease. As noted above, pretreatment with TSHR A-subunit protein only ameliorates induced Graves' disease when injected prior to disease induction by diverting the generation of pathogenic TSHR autoantibodies to a non-pathogenic form detected by ELISA. In contrast, injection of TSHR A-subunit protein after the induction of hyperthyroidism was ineffective [62]. In TSHR/NOD. $\mathrm{H} 2^{\mathrm{h} 4}$ mice that spontaneously develop TSAB, treatment with TSHR A-subunit protein enhanced development of pathogenic TSAb [60]. Limitations of the study in Graves' patients [137] include the small number of subjects, their selection for mild disease, with 4 of 9 attaining euthyroidism (a 'full" response) over a 20 week period. Absent from the study are control individuals with mild disease. If confirmed in a larger double-blind study, this form of immunotherapy would clearly represent a major advance and the first to be effective in established disease.

(ii) In the first use in humans of a TSHR blocking antibody, injections of human mAb K1-70 over an 11 month period reduced the signs and symptoms of severe Graves' ophthalmopathy in a patient with advanced follicular thyroid carcinoma also receiving lenvatinib chemotherapy for much of this period [94]. Unlike immune tolerance induced by immunotherapy, therapy with an antibody will treat, but not cure, disease. This report on a single patient is preliminary, yet given the suboptimal forms of therapy presently available for Graves' ophthalmopathy, K1-70 may prove to be a valuable therapeutic reagent, more specific for the disease than blocking the IGF-1R. 
(iii) Nano-particle delivery of antigens to antigen presenting cells for NPPE generation and presentation to T cells: We have investigated the gold nanoparticle antigen delivery method that prevented onset of Type I diabetes in NOD mice [139]. However, when used with recombinant TSHR A-subunit protein together with the same tolerogenic molecule, spontaneous development of TSAb was not suppressed, but accelerated in hTSHR/NOD. H2 ${ }^{\mathrm{h} 4}$ mice (unpublished data). A more promising method of antigen presentation for the treatment of autoimmunity (that we would have attempted had NIH grant support permitted us to continue) is to use TSHR A-subunit protein encapsulated within, rather than on the surface of, a nanoparticle [140].

\section{Then and Now - The Future of Research in Thyroid Autoimmunity}

When we started working in thyroid autoimmunity, all diseases were equal. However, now some diseases are more equal than others (apologies to George Orwell), at least in the USA. Despite being the most common autoimmune diseases affecting humans, Graves' disease and Hashimoto's thyroiditis are not included among eight autoimmune diseases targeted for investigation by the NIH (https:// www.niaid.nih.gov/diseases-conditions/autoimmune-disease-research). The major reason for this absence, clearly, is economic. Contrary to our idealistic views at the outset of our careers, health care in the USA is now described as an 'industry', doctors as 'providers' and the goal is for 'translational', as opposed to 'basic', investigation leading to more rapid implementation of findings by pharmaceutical companies. We have to accept this reality which, fortunately, did not exist when we were younger.

Nevertheless, there is hope. Although very few in the US, more scientists are involved in basic studies on thyroid autoimmunity in Europe, Japan, and particularly in China. Our hope is that these individuals will receive the necessary incentives and support to continue and to expand their studies. As described above, building on the knowledge of well-defined thyroid autoantigens, approaches are being developed for efficient and safe antigen-specific therapies for Graves' and Hashimoto's diseases, the principles of which could be applied to other organ-specific autoimmune diseases.

\section{Funding}

Previous support from National Institutes of Health grants DK19289 (BR), DK36182 (BR) and DK82390 (SMM), with present support from DK DK54684 (SMM).

\section{Conflict of Interest}

The authors declare that they have no conflict of interest.
References

[1] Rose NR, Witebsky E. Studies on organ specificity. V. Changes in the thyroid glands of rabbits following active immunization with rabbit thyroid extracts. J Immunol 1956; 76: 417-427

[2] Roitt IM, Doniach D, Campbell PN, Hudson RV. Auto-antibodies in Hashimoto's disease (lymphadenoid goitre). Lancet 1956; 271: 820-821

[3] Belyavin G, Trotter WR. Investigations of thyroid antigens reacting with Hashimoto sera. Evidence for an antigen other than thyroglobulin. Lancet 1959; i: 648-652

[4] Adams DD, Purves HD. Abnormal responses in the assay of thyrotropin. Proc Univ Otago Med Sch 1956; 34: 11-12

[5] Meek JC, Jones AE, Lewis UJ, Vanderlaan WP. Characterization of the Long-acting thyroid stimulator of graves' disease. Proc Natl Acad Sci USA 1964; 52: 342-349

[6] Kriss JP, Pleshakov V, Chien JR. Isolation and identification of the long-acting thyroid stimulator and its relation to hyperthyroidism and circumscribed pretibial myxedema. J Clin Endocrinol Metab 1964; 24: 1005-1028

[7] McLachlan SM, McGregor A, Rees Smith B, Hall R. Thyroid-autoantibody synthesis by Hashimoto thyroid lymphocytes. Lancet 1979; 1 : 162-163

[8] McLachlan SM, Rapoport B. The molecular biology of thyroid peroxidase: Cloning, expression and role as autoantigen in autoimmune thyroid disease. Endocr Rev 1992; 13: 192-206

[9] Rapoport B, Chazenbalk GD, Jaume JC, McLachlan SM. The thyrotropin (TSH) receptor: Interaction with TSH and autoantibodies. Endocr Rev 1998; 19: 673-716

[10] McLachlan SM, Rapoport B. Breaking tolerance to thyroid antigens: Changing concepts in thyroid autoimmunity. Endocr Rev 2014; 35: 59-105

[11] Pastan I, Roth J, Macchia V. Binding of hormone to tissue: the first step in polypeptide hormone action. Proc Natl Acad Sci USA 1966; 56: 1802-1809

[12] Rapoport B, Adams RJ. Bioassay of TSH using dog thyroid cells in monolayer culture. Metabolism 1978; 27: 1732-1742

[13] Smith BR, Hall R. Thyroid-stimulating immunoglobulins in Graves' disease. Lancet 1974; 2: 427-431

[14] Smith BR, Bolton J, Young S, Collyer A, Weeden A, Bradbury ], Weightman D, Perros P, Sanders J, Furmaniak J. A new assay for thyrotropin receptor autoantibodies. Thyroid 2004; 14: 830-835

[15] Lytton SD, Li Y, Olivo PD, Kohn LD, Kahaly G]. Novel chimeric thyroid-stimulating hormone-receptor bioassay for thyroid-stimulating immunoglobulins. Clin Exp Immunol 2010; 162: 438-446

[16] Frank CU, Braeth S, Dietrich JW, Wanjura D, Loos U. Bridge technology with TSH receptor chimera for sensitive direct detection of TSH receptor antibodies causing graves' disease: analytical and clinical evaluation. Horm Metab Res 2015; 47: 880-888

[17] Tahara K, Ishikawa N, Yamamoto K, Hirai A, Ito K, Tamura Y, Yoshida Y, Kohn LD. Epitopes for thyroid stimulating and blocking autoantibodies on the extracellular domain of the human thyrotropin receptor. Thyroid 1997; 6: 867-877

[18] Chazenbalk GD, Jaume JC, McLachlan SM, Rapoport B. Engineering the human thyrotropin receptor ectodomain from a non-secreted form to a secreted, highly immunoreactive glycoprotein that neutralizes autoantibodies in Graves' patients' sera. J Biol Chem 1997; 272: 18959-18965

[19] Schwarz-Lauer L, Chazenbalk GD, McLachlan SM, Ochi Y, Nagayama Y, Rapoport B. Evidence for a simplified view of autoantibody interactions with the thyrotropin receptor. Thyroid 2002; 12 : $115-120$ 
[20] Sanders ], Chirgadze DY, Sanders P, Baker S, Sullivan A, Bhardwaja A, Bolton J, Reeve M, Nakatake N, Evans M, Richards T, Powell M, Miguel RN, Blundell TL, Furmaniak J, Smith BR. Crystal structure of the TSH receptor in complex with a thyroid-stimulating autoantibody. Thyroid 2007; 17: 395-410

[21] Nagayama Y, Wadsworth HL, Russo D, Chazenbalk GD, Rapoport B. Binding domains of stimulatory and inhibitory thyrotropin (TSH) receptor autoantibodies determined with chimeric TSH- lutropin/ chorionic gonadotropin receptors. J Clin Invest 1991; 88: 336-340

[22] Morgenthaler NG, Ho SC, Minich WB. Stimulating and blocking thyroid-stimulating hormone (TSH) receptor autoantibodies from patients with Graves' disease and autoimmune hypothyroidism have very similar concentration, TSH receptor affinity, and binding sites. J Clin Endocrinol Metab 2007; 92: 1058-1065

[23] Sanders P, Young S, Sanders J, Kabelis K, Baker S, Sullivan A, Evans M, Clark J, Wilmot J, Hu X, Roberts E, Powell M, Nunez MR, Furmaniak J, Rees SB. Crystal structure of the TSH receptor (TSHR) bound to a blocking-type TSHR autoantibody. J Mol Endocrinol 2011; 46: 81-99

[24] Li Y, Kim J, Diana T, Klasen R, Olivo PD, Kahaly G]. A novel bioassay for anti-thyrotrophin receptor autoantibodies detects both thyroid-blocking and stimulating activity. Clin Exp Immunol 2013; 173: 390-397

[25] Diana T, Wuster C, Olivo PD, Unterrainer A, Konig J, Kanitz M, Bossowski A, Decallonne B, Kahaly GJ. Performance and Specificity of 6 Immunoassays for TSH Receptor Antibodies: A Multicenter Study. Eur Thyroid J 2017; 6: 243-249

[26] Furmaniak J, Sanders J, Rees SB. Blocking type TSH receptor antibodies. Auto Immun Highlights 2013; 4: 11-26

[27] McLachlan SM, Rapoport B. Thyrotropin-blocking autoantibodies and thyroid-stimulating autoantibodies: Potential mechanisms involved in the pendulum swinging from hypothyroidism to hyperthyroidism or vice versa. Thyroid 2013; 23: 14-24

[28] Nunez MR, Sanders J, Chirgadze DY, Furmaniak J, Rees Smith B. Thyroid stimulating autoantibody M22 mimics TSH binding to the TSH receptor leucine rich domain: a comparative structural study of protein-protein interactions. J Mol Endocrinol 2009; 42: 381-395

[29] Evans M, Sanders J, Tagami T, Sanders P, Young S, Roberts E, Wilmot ], Hu X, Kabelis K, Clark J, Holl S, Richards T, Collyer A, Furmaniak J, Smith BR. Monoclonal autoantibodies to the TSH receptor, one with stimulating activity and one with blocking activity, obtained from the same blood sample. Clin Endocrinol (Oxf) 2010; 73: 404-412

[30] Buckland PR, Rickards CR, Howells RD, Davies Jones E, Rees Smith B. Photo-affinity labelling of the thyrotropin receptor. FEBS Lett 1982; 145: 245-249

[31] Davies Jones E, Rees Smith B. A water-soluble fragment of the thyroid-stimulating hormone receptor which binds both thyroid-stimulating hormone and thyroid- stimulating hormone receptor antibodies. J Endocrinol 1984; 100: 113-118

[32] Couet J, de Bernard S, Loosfelt H, Saunier B, Milgrom E, Misrahi M. Cell surface protein disulfide-isomerase is involved in the shedding of human thyrotropin receptor ectodomain. Biochemistry 1996; 35 : 14800-14805

[33] Tanaka K, Chazenbalk GD, McLachlan SM, Rapoport B. The shed thyrotropin receptor is primarily a carboxyl terminal truncated form of the A subunit, not the entire A subunit. Molec Cell Endocrinol 1999; 150: 113-119

[34] Chazenbalk GD, Wang Y, Guo J, Hutchison JS, Segal D, Jaume JC, McLachlan SM, Rapoport B. A mouse monoclonal antibody to a thyrotropin receptor ectodomain variant provides insight into the exquisite antigenic conformational requirement, epitopes and in vivo concentration of human autoantibodies. J Clin Endocrinol Metab 1999; 84: 702-710
[35] Johnstone AP, Cridland JC, DaCosta CR, Harfst E, Shepherd PS. Monoclonal antibodies that recognize the native human thyrotropin receptor. Molec Cell Endocrinol 1994; 105: R1-R9

[36] Da Costa CR, Johnstone AP. Production of the thyrotropin receptor extracellular domain as a glycosylphosphatidylinositol-anchored membrane protein and its interaction with thyrotropin and autoantibodies. J Biol Chem 1998; 273: 11874-11880

[37] Chazenbalk GD, Pichurin P, Chen CR, Latrofa F, Johnstone AP, McLachlan SM, Rapoport B. Thyroid-stimulating autoantibodies in Graves disease preferentially recognize the free A subunit, not the thyrotropin holoreceptor. J Clin Invest 2002; 110: 209-217

[38] Mizutori Y, Chen CR, Latrofa F, McLachlan SM, Rapoport B. Evidence that shed TSH receptor A-subunits drive affinity maturation of autoantibodies causing Graves' disease. J Clin Endocrinol Metab 2009; 94: 927-935

[39] Rapoport B, McLachlan SM. The thyrotropin receptor in Graves' disease. Thyroid 2007; 17: 911-922

[40] Shimojo N, Kohno Y, Yamaguchi K-I, Kikuoka S-I, Hoshioka A, Niimi H, Hirai A, Tamura Y, Saito Y, Kohn LD, Tahara K. Induction of Graves-like disease in mice by immunization with fibroblasts transfected with the thyrotropin repector and a class II molecule. Proc Natl Acad Sci USA 1996; 93: 11074-11079

[41] Costagliola S, Many MC, Denef JF, Pohlenz ], Refetoff S, Vassart G. Genetic immunization of outbred mice with thyrotropin receptor CDNA provides a model of Graves' disease. J Clin Invest 2000; 105: 803-811

[42] Nagayama Y, Kita-Furuyama M, Ando T, Nakao K, Mizuguchi H, Hayakawa T, Eguchi K, Niwa M. A novel murine model of Graves' hyperthyroidism with intramuscular injection of adenovirus expressing the thyrotropin receptor. J Immunol 2002; 168: 2789-2794

[43] Chen C-R, Pichurin P, Nagayama Y, Latrofa F, Rapoport B, McLachlan SM. The thyrotropin receptor autoantigen in Graves' disease is the culprit as well as the victim. J Clin Invest 2003; 111: 1897-1904

[44] Kaneda T, Honda A, Hakozaki A, Fuse T, Muto A, Yoshida T. An improved Graves' disease model established by using in vivo electroporation exhibited long-term immunity to hyperthyroidism in BALB/c mice. Endocrinology 2007; 148: 2335-2344

[45] Moshkelgosha S, So PW, Deasy N, Diaz-Cano S, Banga JP. Cutting edge: Retrobulbar inflammation, adipogenesis, and acute orbital congestion in a preclinical female mouse model of graves' orbitopathy induced by thyrotropin receptor plasmid-in vivo electroporation. Endocrinology 2013; 154: 3008-3015

[46] Chazenbalk G, McLachlan S, Pichurin P, Rapoport B. A prion-like shift between two conformational forms of a recombinant thyrotropin receptor A-subunit module: purification and stabilization using chemical chaperones of the form reactive with Graves' autoantibodies. J Clin Endocrinol Metab 2001; 86: 1287-1293

[47] Chen CR, Hubbard PA, Salazar LM, McLachlan SM, Murali R, Rapoport B. Crystal structure of a TSH receptor monoclonal antibody: Insight into Graves' disease pathogenesis. Mol Endocrinol 2015; 29: 99-107

[48] Rapoport B, Aliesky HA, Chen CR, McLachlan SM. Evidence that TSH receptor a-subunit multimers, not monomers, drive antibody affinity maturation in graves' disease. J Clin Endocrinol Metab 2015; 100: E871-E875

[49] Latif R, Graves P, Davies TF. Oligomerization of the human thyrotropin receptor. Fluorescent protein-tagged hRSHR reveals post-translational complexes. J Biol Chem 2001; 276: 45217-45224

[50] Urizar E, Montanelli L, Loy T, Bonomi M, Swillens S, Gales C, Bouvier M, Smits G, Vassart G, Costagliola S. Glycoprotein hormone receptors: Link between receptor homodimerization and negative cooperativity. EMBO J 2005; 24: 1954-1964 
[51] Pichurin PN, Chen C-R, Chazenbalk GD, Aliesky H, Pham N, Rapoport B, McLachlan SM. Targeted expression of the human thyrotropin receptor A-subunit to the mouse thyroid: Insight into overcoming the lack of response to A-subunit adenovirus immunization. J Immunol 2006; 176: 668-676

[52] Misharin AV, Nagayama Y, Aliesky HA, Rapoport B, McLachlan SM. Studies in mice deficient for the autoimmune regulator (Aire) and transgenic for the thyrotropin receptor reveal a role for Aire in tolerance for thyroid autoantigens. Endocrinol 2009; 150: 29482956

[53] Colobran R, Armengol MP, Faner R, Gartner M, Tykocinski LO, Lucas A, Ruiz M, Juan M, Kyewski B, Pujol-Borrell R. Association of an SNP with intrathymic transcription of TSHR and Graves' disease: A role for defective thymic tolerance. Hum Mol Genet 2011; 20: 3415-3423

[54] Stefan M, Wei C, Lombardi A, Li CW, Concepcion ES, Inabnet WB III, Owen R, Zhang W, Tomer Y. Genetic-epigenetic dysregulation of thymic TSH receptor gene expression triggers thyroid autoimmunity. Proc Natl Acad Sci USA 2014; 111: 12562-12567

[55] McLachlan SM, Nagayama Y, Pichurin PN, Mizutori Y, Chen CR, Misharin A, Aliesky HA, Rapoport B. The link between Graves' disease and Hashimoto's thyroiditis: A role for regulatory T cells. Endocrinology 2007; 148: 5724-5733

[56] McLachlan SM, Alpi K, Rapoport B. Hypothesis and review: Does Graves' disease develop in non-human great apes? Thyroid 2011; 21: 1359-1366

[57] Braley-Mullen H, Yu S. NOD.H-2h4 mice: An important and underutilized animal model of autoimmune thyroiditis and Sjogren's syndrome. Adv Immunol 2015; 126: 1-43

[58] Chen CR, Hamidi S, Braley-Mullen H, Nagayama Y, Bresee C, Aliesky HA, Rapoport B, McLachlan SM. Antibodies to thyroid peroxidase arise spontaneously with age in NOD.H-2h4 mice and appear after thyroglobulin antibodies. Endocrinology 2010; 151: 4583-4593

[59] Rapoport B, Aliesky HA, Banuelos B, Chen CR, McLachlan SM. A unique mouse strain that develops spontaneous, iodine-accelerated, pathogenic antibodies to the human thyrotrophin receptor. J Immunol 2015; 194: 4154-4161

[60] Rapoport B, Banuelos B, Aliesky HA, Hartwig Trier N, McLachlan SM. Critical differences between induced and spontaneous mouse models of Graves' disease with implications for antigen-specific immunotherapy in humans. J Immunol 2016; 197: 4560-4568

[61] Chen CR, Aliesky H, Pichurin PN, Nagayama Y, McLachlan SM, Rapoport B. Susceptibility rather than resistance to hyperthyroidism is dominant in a thyrotropin receptor adenovirus-induced animal model of Graves' disease as revealed by BALB/C-C57BL/ 6 hybrid mice. Endocrinology 2004; 145: 4927-4933

[62] Misharin AV, Nagayama Y, Aliesky H, Mizutori Y, Rapoport B, McLachlan SM. Attenuation of induced hyperthyroidism in mice by pretreatment with thyrotropin receptor protein: deviation of thyroid-stimulating antibody to non-functional antibodies. Endocrinology 2009; 150: 3944-3952

[63] Morshed SA, Ando T, Latif R, Davies TF. Neutral antibodies to the TSH receptor are present in Graves' disease and regulate selective signaling cascades. Endocrinology 2010; 151: 5537-5549

[64] Morshed SA, Ma R, Latif R, Davies TF. Biased signaling by thyroid-stimulating hormone receptor-specific antibodies determines thyrocyte survival in autoimmunity. Sci Signal 2018; 11: pii: eaah4120. doi:10.1126/scisignal.aah4120

[65] Morshed SA, Ma R, Latif R, Davies TF. How one TSH receptor antibody induces thyrocyte proliferation while another induces apoptosis. J Autoimmun 2013; 47: 17-24

[66] Rapoport B, McLachlan SM. TSH receptor cleavage into subunits and shedding of the A-subunit; a molecular and clinical perspective. Endocr Rev 2016; 37: 114-134
[67] Latif R, Morshed SA, Zaidi M, Davies TF. The thyroid-stimulating hormone receptor: impact of thyroid-stimulating hormone and thyroid-stimulating hormone receptor antibodies on multimerization, cleavage, and signaling. Endocrinol Metab Clin North Am 2009; 38: 319-341 viii

[68] Loosfelt H, Pichon C, Jolivet A, Misrahi M, Caillou B, Jamous M, Vannier B, Milgrom E. Two-subunit structure of the human thyrotropin receptor. Proc Natl Acad Sci USA 1992; 89: 3765-3769

[69] Misrahi M, Milgrom E. Cleavage and shedding of the TSH receptor. Eur J Endocrinol 1997; 137: 599-602

[70] Vassart G, Costagliola S. A physiological role for the posttranslational cleavage of the thyrotropin receptor? Endocrinology 2004; 145: 1-3

[71] Furmaniak J, Hashim FA, Buckland PR, Petersen VB, Beever K, Howells RD, Rees Smith B. Photoaffinity labelling of the TSH receptor on FRTL5 cells. FEBS Lett 1987; 215: 316-322

[72] Chen CR, Chazenbalk GD, Wawrowsky KA, McLachlan SM, Rapoport B. Evidence that human thyroid cells express uncleaved, single-chain thyrotropin receptors on their surface. Endocrinology 2006; 147: 3107-3113

[73] Sanders J, Evans M, Premawardhana LD, Depraetere H, Jeffreys J, Richards T, Furmaniak J, Rees SB. Human monoclonal thyroid stimulating autoantibody. Lancet 2003; 362: 126-128

[74] Sanders J, Evans M, Betterle C, Sanders P, Bhardwaja A, Young S, Roberts E, Wilmot J, Richards T, Kiddie A, Small K, Platt H, Summerhayes S, Harris R, Reeve M, Coco G, Zanchetta R, Chen S, Furmaniak J, Rees Smith B. A human monoclonal autoantibody to the thyrotropin receptor with thyroid stimulating blocking activity. Thyroid 2008; 18 : 735-746

[75] Davies TF, Laurberg P, Bahn RS. Hyperthyroid Disorders. In: Melmed S, Polonsky KS, Reed Larsen P, Kronenberg HM. (eds) Williams Textbook of Endocrinology. 13th ed. Philadelphia, PA: Elsevier; 2016380

[76] Rosenbaum JT, Choi D, Wong A, Wilson DJ, Grossniklaus HE, Harrington CA, Dailey RA, Ng JD, Steele EA, Czyz CN, Foster JA, Tse D, Alabiad C, Dubovy S, Parekh PK, Harris G], Kazim M, Patel PJ, White VA, Dolman PJ, Edward DP, Alkatan HM, Al Hussain H, Selva D, Yeatts RP, Korn BS, Kikkawa DO, Stauffer P, Planck SR. The role of the immune response in the pathogenesis of thyroid eye disease: $\mathrm{A}$ Reassessment. PLoS One 2015; 10: e0137654

[77] Kumar S, Iyer S, Bauer H, Coenen M, Bahn RS. A stimulatory thyrotropin receptor antibody enhances hyaluronic acid synthesis in Graves' orbital fibroblasts: Inhibition by an IGF-I receptor blocking antibody. J Clin Endocrinol Metab 2012; 97: 1681-1687

[78] Krieger CC, Gershengorn MC. A modified ELISA accurately measures secretion of high molecular weight hyaluronan (HA) by Graves' disease orbital cells. Endocrinology 2014; 155: 627-634

[79] Winand R]. Increased urinary excretion of acidic mucopolysaccharides in exophthalmos. J Clin Invest 1968; 47: 2563-2568

[80] Yarman S, Gokkusu C, Turkoglu UM, Ademoglu E, Alagol F. Urinary glycosaminoglycans levels in patients with Graves' ophthalmopathy: And effective parameter for the grading of ophthalmopathy. Med Sci Res 1996; 24: 647-648

[81] Hansen C, Fraiture B, Rouhi R, Otto E, Forster G, Kahaly G. HPLC glycosaminoglycan analysis in patients with Graves' disease. Clin Sci (Colch ) 1997; 92: 511-517

[82] Rapoport B, Alsabeh R, Aftergood D, McLachlan SM. Elephantiasic pretibial myxedema: insight into and a hypothesis regarding the pathogenesis of the extrathyroidal manifestations of Graves' disease. Thyroid 2000; 10: 685-692

[83] Cianfarani F, Baldini E, Cavalli A, Marchioni E, Lembo L, Teson M, Persechino S, Zambruno G, Ulisse S, Odorisio T, D'Armiento M. TSH receptor and thyroid-specific gene expression in human skin. J Invest Dermatol 2010; 130: 93-101

[84] Miller RA. The Koebner phenomenon. Int ] Dermatol 1982; 21: 192-197 
[85] Smith T], Kahaly G], Ezra DG, Fleming JC, Dailey RA, Tang RA, Harris G], Antonelli A, Salvi M, Goldberg RA, Gigantelli JW, Couch SM, Shriver EM, Hayek BR, Hink EM, Woodward RM, Gabriel K, Magni G, Douglas RS. Teprotumumab for Thyroid-Associated Ophthalmopathy. N Engl J Med 2017; 376: 1748-1761

[86] Tramontano D, Cushing GW, Moses AC, Ingbar SH. Insulin-like growth factor-I stimulates the growth of rat thyroid cells in culture and synergizes the stimulation of DNA synthesis induced by TSH and Graves'-IgG. Endocrinol 1986; 119: 940-942

[87] Weightman DR, Perros P, Sherif IH, Kendall-Taylor P. Autoantibodies to IGF-1 binding sites in thyroid associated ophthalmopathy. Autoimmunity 1993; 16: 251-257

[88] Pritchard J, Han R, Horst N, Cruikshank WW, Smith T]. Immunoglobulin activation of $\mathrm{T}$ cell chemoattractant expression in fibroblasts from patients with Graves' disease is mediated through the insulin-like growth factor I receptor pathway. J Immunol 2003; 170: 6348-6354

[89] Tsui S, Naik V, Hoa N, Hwang C], Afifiyan NF, Sinha Hikim A, Gianoukakis AG, Douglas RS, Smith TJ. Evidence for an association between thyroid-stimulating hormone and insulin-like growth factor 1 receptors: A tale of two antigens implicated in Graves' disease. J Immunol 2008; 181: 4397-4405

[90] Minich WB, Dehina N, Welsink T, Schwiebert C, Morgenthaler NG, Kohrle J, Eckstein A, Schomburg L. Autoantibodies to the IGF1 Receptor in Graves' Orbitopathy. J Clin Endocrinol Metab 2013; 98: 752-760

[91] Krieger CC, Place RF, Bevilacqua C, Marcus-Samuels B, Abel BS, Skarulis MC, Kahaly G], Neumann S, Gershengorn MC. TSH/IGF-1 Receptor Cross Talk in Graves' Ophthalmopathy Pathogenesis. J Clin Endocrinol Metab 2016; 101: 2340-2347

[92] Marcus-Samuels B, Krieger CC, Boutin A, Kahaly G], Neumann S, Gershengorn MC. Evidence That Graves' Ophthalmopathy Immunoglobulins Do Not Directly Activate IGF-1 Receptors. Thyroid 2018; 28 : 650-655

[93] Ma H, Zhang T, Shen H, Cao H, Du J. The adverse events profile of anti-IGF-1R monoclonal antibodies in cancer therapy. $\mathrm{Br}$ J Clin Pharmacol 2014; 77: 917-928

[94] Furmaniak J, Castro MR, Wentworth M, Algeciras A, Morris JC, Garrity J, Wikmot J, Kabelis K, Sanders J. Blocking the TSH receptor with the human monoclonal antibody K1-70 (TM) improves Graves' ophthalmopathy and aids control of advanced follicular thyroid carcinoma- results of long term treatment under the first in human single patient expanded use therapy. Eur. Thyroid J 2018; 7: 1 (Abstract)

[95] Neumann S, Kleinau G, Costanzi S, Moore S, Jiang JK, Raaka BM, Thomas C], Krause G, Gershengorn MC. A low-molecular-weight antagonist for the human thyrotropin receptor with therapeutic potential for hyperthyroidism. Endocrinology 2008; 149: 5945-5950

[96] .Van Koppen C], de Gooyer ME, Karstens W], Plate R, Conti PG, van Achterberg TA, van Amstel MG, Brands JH, Wat J, Berg RJ, Lane JR, Miltenburg AM, Timmers CM. Mechanism of Action of a Nanomolar Potent, Allosteric Antagonist of the Thyroid-Stimulating Hormone Receptor. Br J Pharmacol 2012; 165: 2314-2324

[97] Latif R, Ali MR, Ma R, David M, Morshed SA, Ohlmeyer M, Felsenfeld DP, Lau Z, Mezei M, Davies TF. New small molecule agonists to the thyrotropin receptor. Thyroid 2015; 25: 51-62

[98] Stan MN, Garrity JA, Carranza Leon BG, Prabin T, Bradley EA, Bahn RS. Randomized controlled trial of rituximab in patients with Graves' orbitopathy. J Clin Endocrinol Metab 2015; 100: 432-441

[99] Salvi M, Vannucchi G, Curro N, Campi I, Covelli D, Dazzi D, Simonetta S, Guastella C, Pignataro L, Avignone S, Beck-Peccoz P. Efficacy of B-cell targeted therapy with rituximab in patients with active moderate to severe Graves' orbitopathy: A randomized controlled study. J Clin Endocrinol Metab 2015; 100: 422-431
[100] Salvi M, Vannucchi G, Campi I, Curro N, Dazzi D, Simonetta S, Bonara P, Rossi S, Sina C, Guastella C, Ratiglia R, Beck-Peccoz P. Treatment of Graves' disease and associated ophthalmopathy with the anti-CD20 monoclonal antibody rituximab: an open study. Eur J Endocrinol 2007; 156: 33-40

[101] Rajaii F, McCoy AN, Smith T]. Cytokines are both villains and potential therapeutic targets in thyroid-associated ophthalmopathy: From bench to bedside. Expert Rev Ophthalmol 2014; 9: 227-234

[102] Li B, Smith TJ. PI3K/AKT pathway mediates induction of IL-1RA by TSH in fibrocytes: modulation by PTEN. J Clin Endocrinol Metab 2014; 99: 3363-3372

[103] Fernando R, Lu Y, Atkins S], Mester T, Branham K, Smith TJ. Expression of thyrotropin receptor, thyroglobulin, sodium-iodide symporter, and thyroperoxidase by fibrocytes depends on AIRE. J Clin Endocrinol Metab 2014; 99: E1236-E1244

[104] Wang H, Atkins SJ, Fernando R, Wei RL, Smith TJ. Pentraxin-3 is a TSH-Inducible protein in human fibrocytes and orbital fibroblasts. Endocrinology 2015; 156: 4336-4344

[105] Fernando R, Atkins SJ, Smith TJ. Intersection of Chemokine and TSH Receptor Pathways in Human Fibrocytes: Emergence of CXCL-12/ CXCR4 Cross Talk Potentially Relevant to Thyroid-Associated Ophthalmopathy. Endocrinology 2016; 157: 3779-3787

[106] Wu T, Mester T, Gupta S, Sun F, Smith TJ, Douglas RS. Thyrotropin and CD40L Stimulate Interleukin-12 Expression in Fibrocytes: Implications for Pathogenesis of Thyroid-Associated Ophthalmopathy. Thyroid 2016; 26: 1768-1777

[107] Mester T, Raychaudhuri N, Gillespie EF, Chen H, Smith T], Douglas RS. CD40 Expression in Fibrocytes Is Induced by TSH: Potential Synergistic Immune Activation. PLoS One 2016; 11: e0162994

[108] Fernando R, Grisolia ABD, Lu Y, Atkins S, Smith T]. Slit2 modulates the inflammatory phenotype of orbit-infiltrating fibrocytes in graves' disease. J Immunol 2018; 200: 3942-3949

[109] Hanafusa T, Pujol-Borrell R, Chiovato L, Russell RCG, Doniach D, Bottazzo GF, Feldmann M. Aberrant expression of HLA-DR antigen on thyrocytes in Graves' disease: Relevance for autoimmunity. Lancet 1983; ii: 1111-1115

[110] Londei M, Lamb JR, Bottazzo GF, Feldmann M. Epithelial cells expressing aberrant MHC class II determinants can present antigen to cloned human T cells. Nature 1984; 312: 639-641

[111] Todd JA, Acha-Orbea H, Bell Jl, Chao N, Fronek Z, Jacob CO, McDermott M, Sinha AA, Timmerman L, Steinman L, McDevitt HO. A molecular basis for MHC Class II - Associated autoimmunity. Science 1988; 240: 1003-1009

[112] Kohling HL, Plummer SF, Marchesi JR, Davidge KS, Ludgate M. The microbiota and autoimmunity: Their role in thyroid autoimmune diseases. Clin Immunol 2017; 183: 63-74

[113] McLachlan SM, Pegg CAS, Atherton MC, Middleton SM, Clark F, Rees Smith B. TSH receptor antibody synthesis by thyroid lymphocytes. Clin Endocrinol 1986; 24: 223-230

[114] Foti D, Kaufman KD, Chazenbalk GD, Rapoport B. Generation of a biologically-active, secreted form of human thyroid peroxidase by site-directed mutagenesis. Mol Endocrinol 1990; 4: 786-791

[115] Chazenbalk GD, Portolano S, Russo D, Hutchison JS, Rapoport B, McLachlan SM. Human organ-specific autoimmune disease: Molecular cloning and expression of an autoantibody gene repertoire for a major autoantigen reveals an antigenic dominant region and restricted immunoglobulin gene usage in the target organ. J Clin Invest 1993; 92: 62-74

[116] Portolano S, McLachlan SM, Rapoport B. High affinity, thyroid-specific human autoantibodies displayed on the surface of filamentous phage use $\mathrm{V}$ genes similar to other autoantibodies. J Immunol 1993; 151: 2839-2851 
[117] Portolano S, Chazenbalk GD, Seto P, Hutchison JS, Rapoport B, McLachlan SM. Recognition by recombinant autoimmune thyroid disease-derived Fab fragments of a dominant conformational epitope on human thyroid peroxidase. J Clin Invest 1992; 90: 720-726

[118] Latrofa F, Phillips M, Rapoport B, McLachlan SM. Human monoclonal thyroglobulin autoantibodies: epitopes and immunoglobulin genes. J Clin Endocrinol Metab 2004; 89: 5116-5123

[119] McIntosh RS, Asghar MS, Kemp EH, Watson PF, Gardas A, Banga JP, Weetman AP. Analysis of IgG kappa anti-thyroid peroxidase antibodies from different tissues in Hashimoto's thyroiditis. J Clin Endocrinol Metab 1997; 82: 3818-3825

[120] Chapal N, Peraldi-Roux S, Bresson D, Pugniere M, Mani JC, Granier C, Baldet L, Guerrier B, Pau B, Bouanani M. Human anti-thyroid peroxidase single-chain fragment variable of $\mathrm{Ig}$ isolated from a combinatorial library assembled in-cell: Insights into the in vivo situation. J Immunol 2000; 164: 4162-4169

[121] Mclntosh RS, Asghar MS, Watson PF, Kemp EH, Weetman AP. Cloning and analysis of IgG kappa and IgG lambda anti-thyroglobulin autoantibodies from a patient with Hashimoto's thyroiditis. Evidence for in vivo antigen-driven repertoire selection. J Immunol 1996; 157: 927-935

[122] Farrar ], Portolano S, Willcox N, Vincent A, Jacobson L, Newsom-Davis ], Rapoport B, McLachlan SM. Diverse Fab specific for acetylcholine receptor epitopes from a myasthenia gravis thymus combinatorial library. Int Immunol 1997; 9: 1311-1318

[123] McLachlan SM, Rapoport B. Thyroid Peroxidase as an Autoantigen. Thyroid 2007; 17: 939-948

[124] McLachlan SM, Rapoport B. Thyroid autoantibodies display both "original antigenic sin" and epitope spreading. Front Immunol 2017; 8: 1845

[125] Latrofa F, Pichurin P, Guo J, Rapoport B, McLachlan SM. Thyroglobulin-thyroperoxidase autoantibodies are polyreactive, not bispecific: Analysis using human monoclonal autoantibodies. J Clin Endocrinol Metab 2003; 88: 371-378

[126] Chacko S, Padlan E, Portolano S, McLachlan SM, Rapoport B. Structural studies of human autoantibodies. Crystal structure of a thyroid peroxidase autoantibody Fab. J Biol Chem 1996; 271: 12191-12198

[127] Dayan CM, Londei M, Corcoran AE, Grubeck-Loebenstein B, James RFL, Rapoport B, Feldmann M. Autoantigen recognition by thyroid-infiltrating T cells in Graves disease. Proc Natl Acad Sci USA 1991; 88: 7415-7419

[128] Quaratino S, Badami E, Pang YY, Bartok I, Dyson J, Kioussis D, Londei M, Maiuri L. Degenerate self-reactive human T-cell receptor causes spontaneous autoimmune disease in mice. Nat Med 2004; 10 : 920-926

[129] Li CW, Osman R, Menconi F, Concepcion ES, Tomer Y. Flexible peptide recognition by HLA-DR triggers specific autoimmune T-cell responses in autoimmune thyroiditis and diabetes. J Autoimmun 2017; 76: 1-9
[130] Ehlers M, Thiel A, Bernecker C, Porwol D, Papewalis C, Willenberg HS, Schinner S, Hautzel H, Scherbaum WA, Schott M. Evidence of a combined cytotoxic thyroglobulin and thyroperoxidase epitope-specific cellular immunity in Hashimoto's thyroiditis. J Clin Endocrinol Metab 2012; 97: 1347-1354

[131] Muixi L, Carrascal M, Alvarez I, Daura X, Marti M, Armengol MP, Pinilla C, Abian J, Pujol-Borrell R, Jaraquemada D. Thyroglobulin peptides associate in vivo to HLA-DR in autoimmune thyroid glands. J Immunol 2008; 181: 795-807

[132] Lanzavecchia A. Receptor-mediated antigen uptake and its effect on antigen presentation to class II-restricted T lymphocytes. Ann Rev Immunol 1990; 8: 773-793

[133] Guo J, Quaratino S, Jaume JC, Costante G, Londei M, McLachlan SM, Rapoport B. Autoantibody-mediated capture and presentation of autoantigen to $T$ cells via the $\mathrm{Fc}$ epsilon receptor by a recombinant human autoantibody Fab converted to IgE. J Immunol Meth 1996; 195: 81-92

[134] Guo J, Yan X-M, McLachlan SM, Rapoport B. Search for the autoantibody immunodominant region on thyroid peroxidase: Epitopic footprinting with a human monoclonal autoantibody locates a facet on the native antigen containing a highly conformational epitope. J Immunol 2001; 166: 1327-1333

[135] Guo J, McLachlan SM, Rapoport B. Antibodies focused on the human autoantibody immunodominant region are induced by $B$ lymphocytes that constitutively express thyroid peroxidase diverted to the major histocompatibility complex II pathway. Thyroid 2006; 16 : 343-349

[136] Smith MJ, Rihanek M, Coleman BM, Gottlieb PA, Sarapura VD, Cambier JC. Activation of thyroid antigen-reactive B cells in recent onset autoimmune thyroid disease patients. J Autoimmun 2018; 89: 82-89

[137] Pearce S, Razvi S, Boelaert K, Gilbert J, Wernig F, Muller I, Dayan C, Highham C, Murray R, Vaidya B, Kahaly GL, Barrell K, Carnegie C, Jansson L, Martin K. Antigen-specific immune modulation using TSH receptor peptides (ATX-GD-59) for Graves' hyperthyroidism: 'Results of a First-in-human' study. Eur Thyroid J 2018; 7: 1 (Abstract)

[138] Jansson L, Vrolix K, Jahraus A, Martin KF, Wraith DC. Immunotherapy with apitopes blocks the immune response to thyroid stimulating hormone receptor in HLA-DR transgenic mice. Endocrinology 2018; 159: $3446-3457$

[139] Yeste A, Takenaka MC, Mascanfroni ID, Nadeau M, Kenison JE, Patel B, Tukpah AM, Babon JA, DeNicola M, Kent SC, Pozo D, Quintana FJ. Tolerogenic nanoparticles inhibit T cell-mediated autoimmunity through SOCS2. Sci Signal 2016; 9: ra61

[140] McCarthy DP, Yap JW, Harp CT, Song WK, Chen J, Pearson RM, Miller SD, Shea LD. An antigen-encapsulating nanoparticle platform for TH1/17 immune tolerance therapy. Nanomedicine 2017; 13: 191-200 